25. On the External and Cranial Characters of the European Badger (Meles) and of the American Badger (Taxidea)* By R. I. Pocock, F.R.S.

[Received May 22, 1920 : Read June 15, 1920.]

(Text-figures 19-25.)

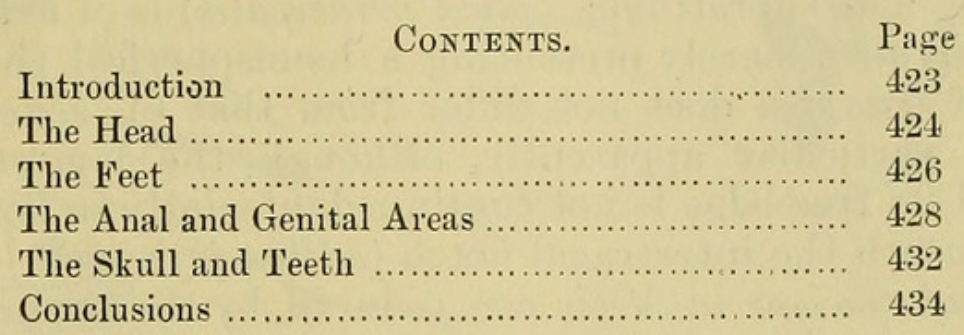

\title{
Introduction.
}

Many descriptions have been published of the European and American Badgers t, and the wide divergences between them in the structure of the skull and teeth were long ago insisted upon by Baird ; but although attention bas been drawn to some of the differences in external characters, it seems that dried skins have been in all cases the only material available for the purpose. So far as I am aware, no author has had the opportunity hitherto of instituting a comparison between the genera based upon fresh material; and no one appears to have questioned the right of Taxidea to be included in the same subfamily as Meles. Even Gray $\div$, who split his family Melinidæ (= Melince of many recent authors) into the five tribes-Melina, Mellivorina, Mephitina, Zorillina, and Helictidina, ranged Taxidea alongside Meles, being evidently of opinion that the kinship between these two genera is closer than the kinship between Meles and Arctonyx.

As will appear in the sequel, the outcome of my comparison between the external characters-supplemented by cranial and dental characters - of the two types is to suggest that the likenesses between them are superficial, adaptive, and due to similarity of habits, and that the differences between them do not justify their relegation to the same tribe or subfamily. It will be remembered that Mellivora was also formerly assigned to the Melince on account of its badger-like build and feet; but the tendency of modern opinion is to regard the genus as a

* The facts recorded in this paper are based upon specimens examined at the Society's Prosectorium.

+ The most exhaustive and most recent description of the skull and teeth of Meles known to me may be found in the 'Catalogue of the Mammals of Western Europe' ty Miller. The external characters, based upon an examination of dried skins, are, however, briefly dismissed. Coues gave a long and on the whole accurate description of Taxidea in his volume on Fur-bearing Animals, 1877.

‡ Cat. Carnivorous etc. Mammalia, 1869, pp. 120-121. Gill (Smithsonian Misc. Coll. xi. pp. 64-66, 1872) adopted Gray's subdivisions, but converted the tribes of Melinidæ into subfamilies of the Mustelidæ. Coues followed Gill. 
specialized member of the Mustelince or to place it in a subfamily apart*.

\section{The Head.}

The forehead is higher and rounder in Meles than in Taxidea. The ear of Meles is moderately large with tolerably evenly rounded edge. It is simple in structure, the bursa being suppressed; the tragus is small and the antitragus scarcely developed. The supratragus (plica principalis) is of average size but not valvular, merely presenting a hemispherical thickening. The ear of Taxidea does not differ from that of Meles in any important particular apparently, although the lamina is less salient and its free edge is not continued inferiorly so far towards a point beneath the intertragal notch (aditus inferior).

The fasial vibrissa in Meles are reduced by the suppression of the interramal tuft, and the superior genal tuft is at most represented by one short bristle at least in the specimens examined. The mystacial and submental vibrissæe are morlerately well developed, one of the latter on each side being exceptionally long; the inferior genal tuft is represented by one or two bristles behind the corner of the mouth and the superciliary tuft by two or more over the eye. In Taxidea the tufts are normal in number and situation, the genal tufts being represented by about three bristles, the upper being some distance below the level of the eye; but the interramal tuit has only about two short bristles.

The nose of Meles is produced and snout-like, and overlaps the under jaw considerably. The rhinarium is exceptionally large; its upper surface is naked as far back as a line behind the posterior ends of the nostrils. The anterior surface forms a wide, deep, flat disc, without trace of a median groove. The inner expander portion of the nostril is large, the outer forms a long narrow slit extending horizontally to the lateral edge of the rhinarium. The infranarial portion is exceptionally deep and well developer both mesially and laterally; its inferior edge is convex, but varies in the degree of convexity, and is sometimes p:oluced into a point in the middle line; but there is no philtrum and the upper lip is hairy across the middle and uncleft.

Judging from descriptions, the rhinarium of Arctonyx, which has been compared to that of a pig, resembles tolerably closely the rhinarium of Meles.

The nose of Taxidea is less developed and less snout-like than that of Meles. It does not overlap the lower jaw to the same extent, and is not so deep from the summit of the rhinarium to the erlge of the upper lip. The rhinarium itself also differs from that of Meles in being covered above with hair nearly up to its anterior edge, in having an anterior median groove, and in

* See my paper on Mellivora and Gulo (P. Z. S. 1920, pp. 179-187).

† Figured and described by Boas, Ohrknorpel der Säug. p. 150, pl. xxi. fig. 221 (1912). 
Text-figure 19.

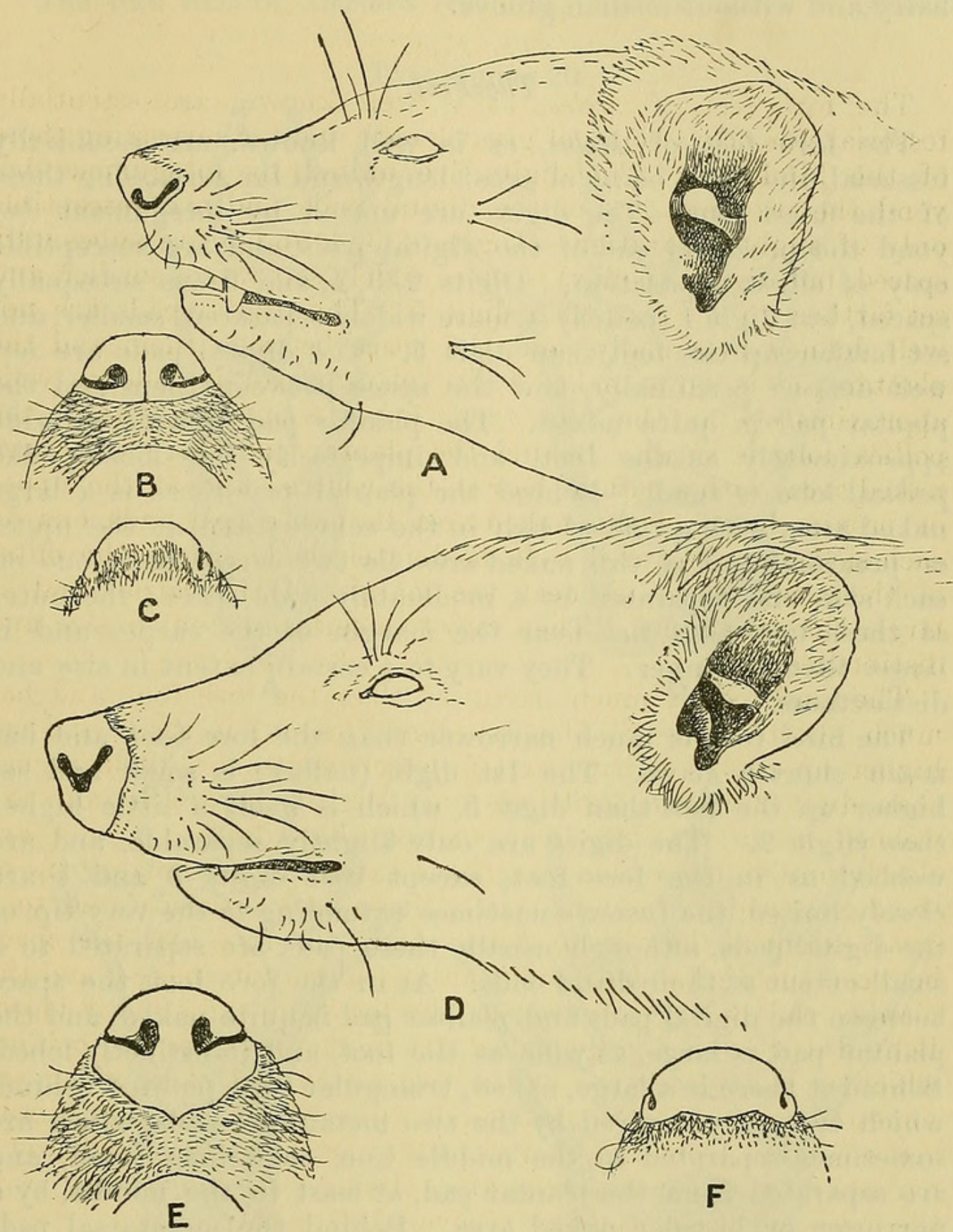

A. Side view of head of Taxidea americana.

B. Rhinarium and upper lip of the same, from the front.

C. Rhinarium of the same, firom above.

D. Side view of head of Meles meles.

E. Rhinarium and upper lip of the same, from the front.

F. Rhinarium of the same, from above.

$$
\times \frac{1}{2} \text {. }
$$

(In B and E the rhinarium and upper lip are represented in the same plane, so that the lip is not foreshortened.) 
having a shallow infranarial portion on each side. As in Meles, however, there is no philtrum, the upper lip being continuously hairy and without median groove.

\section{The Feet.}

The fore feet of Meles, as is weil known, are essentially fossorial, the claws being of great length and far surpassing those of the hind foot. The digits are united by integument beyond the proximal end of the digital pads, and are susceptible only of slight separation. Digits $2,3,4$, and 5 are subequally spaced, but digit 1 (pollex) is more widely separated, smaller, and set farther up the foot than digit 5 . The digital pads are not well defined proximally, and the space between them and the plantar pad is quite naked. The plantar pad is wide, as wide approximately as the foot, and imperfectly four-lobed; the pollical lobe is small. Behind the plantar pad there is a large naked area, with a tuft of hair in the centre; and at the upper or proximal end of this naked area lie two carpal pads, one on each side and separated by a moderately wide space; the outer of these two pads lies near the margin of the carpus and is larger than the inner. They vary to a certain extent in size and distinctness.

The hind foot is much narrower than the fore foot and has much shorter claws. The 1st digit (hallux) is small and set higher up the foot than digit 5, which is itself a little higher than digit 2. The digits are only slightly separable, and are webbed as in the fore foot, except that digits 3 and 4 are closely united, the fusion sometimes extending to the very tip of the digital pads, although usually these pads are separated to a small extent at their distal ends. As in the fore foot, the space between the digital pads and plantar pad is quite naked, and the plantar pad is large, as wide as the foot, and indistinctly lobed. Behind it there is a large, naked, triangular area, pointed behind, which is mostly covered by the two metatarsal pads, which are sometimes separated in the middle line, sometimes fused, and are separated from the plantar pad, at least in the middle, by a narrower or broader naked area. Behind the metatarsal pads the lower surface of the foot is covered with hair.

Hodgson's illustrations* of the feet of Meles leucurus attest their similarity to those of Meles meles, and unpublished sketches of the feet of Arctonyx by this author show that they resemble the feet of Meles in general features. Perhaps the plantar pads are a little narrower and more decidedly trilobate, and no mat of hair is shown on the area between the plantar and carpal pads; but two carpal pads are shown on the fore foot and two metatarsal pads in the centre of a naked area on the

* Journ. Asiatic Soc. Bengal, xvi. pl. ii. (1897). It may be noted that on this plate the sketch of the hind foot of Helictis nipalensis is labelled Urva cancrivora, and that of the latter is similarly labelled Helictis nipalensis. 
hind foot, but this area is larger than in Meles and the hairy area up to the heel is shorter.

The fore foot of T'axidea resembles that of Meles in general

Text-figure 20.

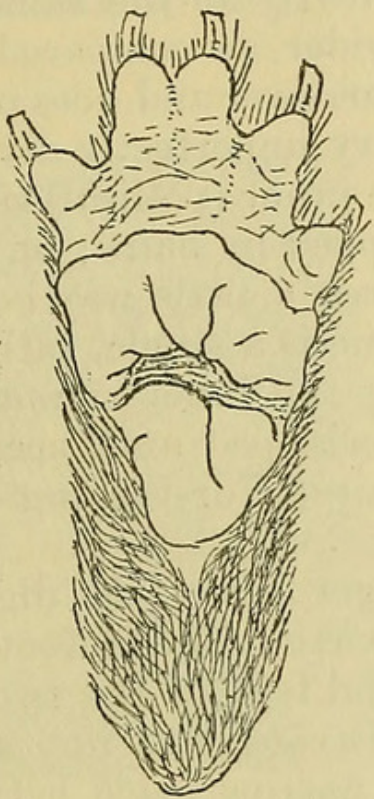

A

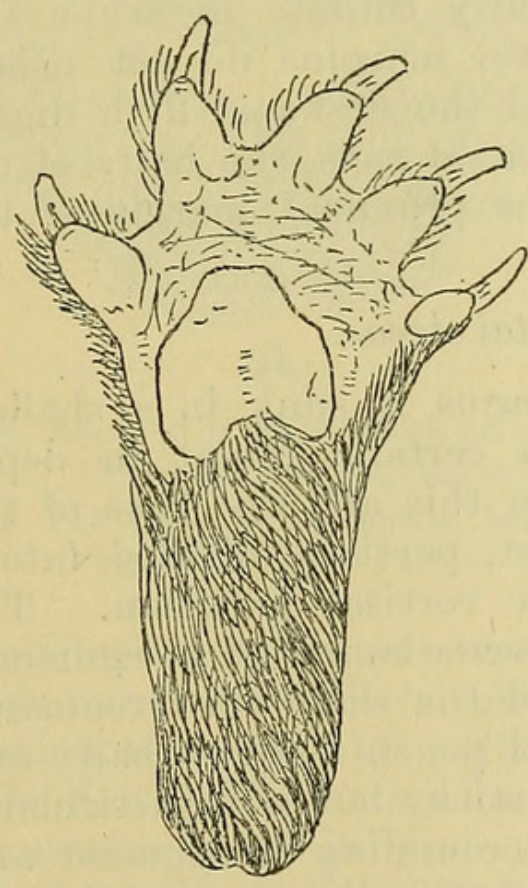

C

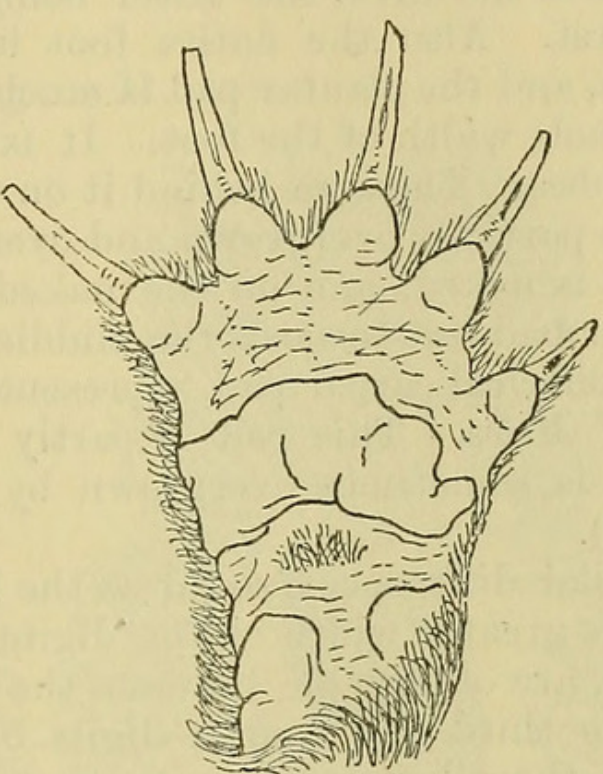

B

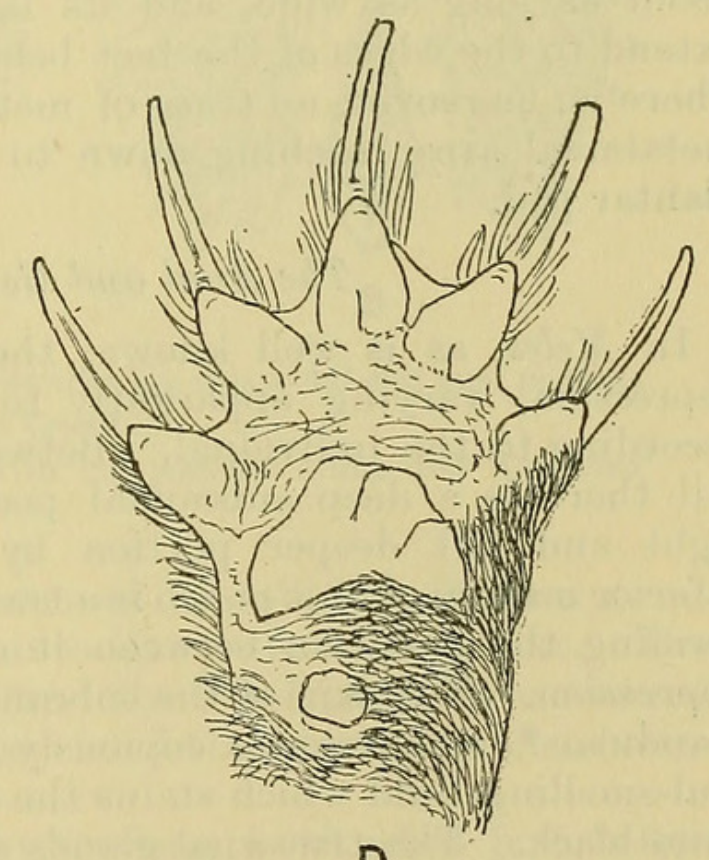

D

A. Right hind foot of Meles meles.

B. Right fore foot of the same.

C. Right hind foot of Taxidea americana.

D. Right fore foot of the same.

$\times \frac{1}{2}$.

form, in the length and strength of the fossorial claws, and in the nakedness of the area between the digital and plantar pads ; 
but it differs in many structural details. The pirifer'm digital pads are much larger and better defined along their proximal margin, and those of the second, third, and fourth digits are united by webbing extending past the middle of each, these three digits being closer together than the second is to the first or the fourth to the fifth, the latter being nearly at the same level as the first. Also the entire foot is wider as compared with its length, and the plantar pad is much narrower and does not occupy the whole width of the foot. It is very imperfectly divided into four lobes. The area behind it on the inner (pollical) side of the foot is partially overgrown and overlapped by hairs; on the outer side it is naked, and on the naked area a little way behind the plantar pad but towards the middle line is a single, rather small, hemispherical carpal pad, representing the inner or radial carpal pad of Meles. This pad is partly overlapped and, according to Coues, is sometimes overgrown by hair ('Fur-bearing Animals,' p. 266).

Similai differences, so far as the larger size of the digital pads and the greater width of the digital portion of the foot are concerned, are observable between the hind feet of the two genera; but the third and fourth digits of Taxidea are not so closely united, there being a definite, though narrow space between the inner proximal ends of the pads. The plantar pad is very different in Taxidea. It is irregularly cordate in shape and about as long as wide, and its lateral margins ro not nearly extend to the edges of the feet behind the first and fifth digits. There is, moreover, no trace of metatarsal pads, the hairs of the metatarsal area reaching down to the proximal margin of the plantar pad.

\section{The Anal and Genital Areas.}

In Meles, as is well known, the anus is sunk in a shallow depression, varying apparently to a certain extent in depth according to the individual. Between this and the base of the tail there is a deep subcaudal pocket, partially divided into a right and left deeper portion by a vertical partition. The inferior margin of this pouch is a transverse lamina of integument, forming the partition between it and the shallower circumanal depression. The skin of the subcaudal pouch itself is hairy and glandular *, and secretes copiously a sticky but not particularly foul-smelling fluid which stains the surrounding integument and hairs black. The true anal glands do not discharge directly into this subcaudal pouch, but just within the orifice of the anus as in all Mustelidæ. I have verified the existence of this pouch in the Japanese Badger ( $M$. anakuma), and, according to M. Edwards, it is present in the Tibetan species (M. leucurres). It is also present in the Oriental genus Arctonyx, as recorded by Evans in

* As fully described by Chatin, Ann. Sci. Nat. (5) xix. pp. 106-109, pl. vii. figs. 66-67 (1874). 
the following passage :- "[there] is a caudal pouch directly under the origin of the tail, . . . but quite distinct from, and wholly unconnected with, the anus or genital organs. The sac is formed by duplicate folds of the common integument, having a lining of naked membrane, secreting a brown unctuous matter, not unlike cerumen, or wax of the ear" "*.

\section{Text-figure 21.}

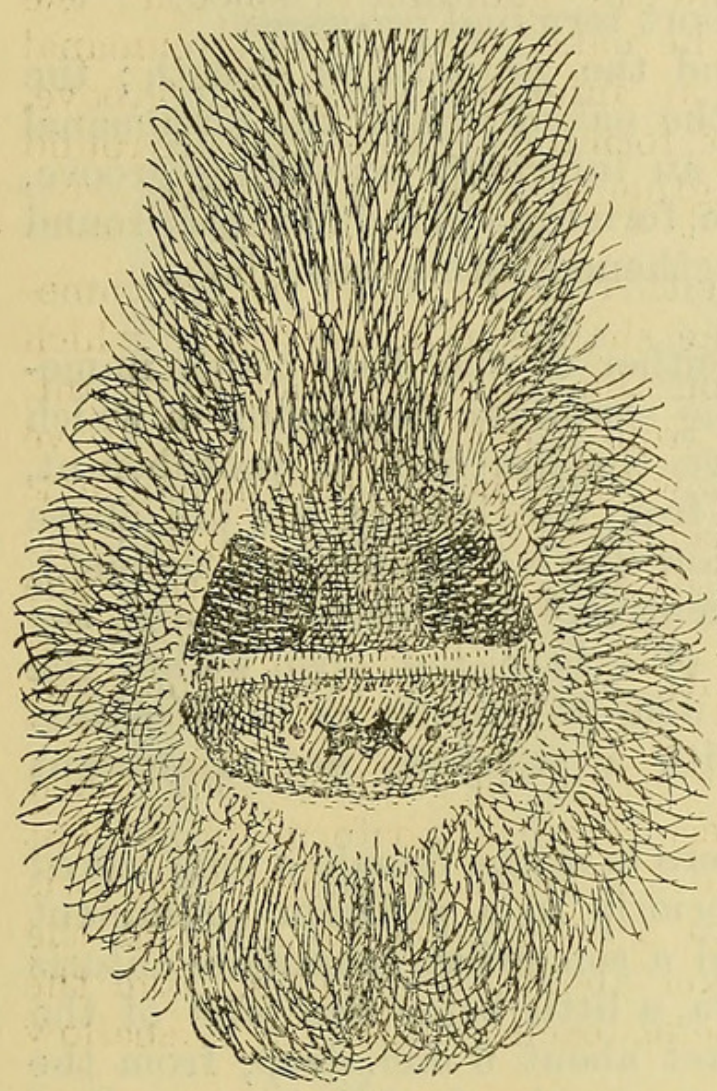

A

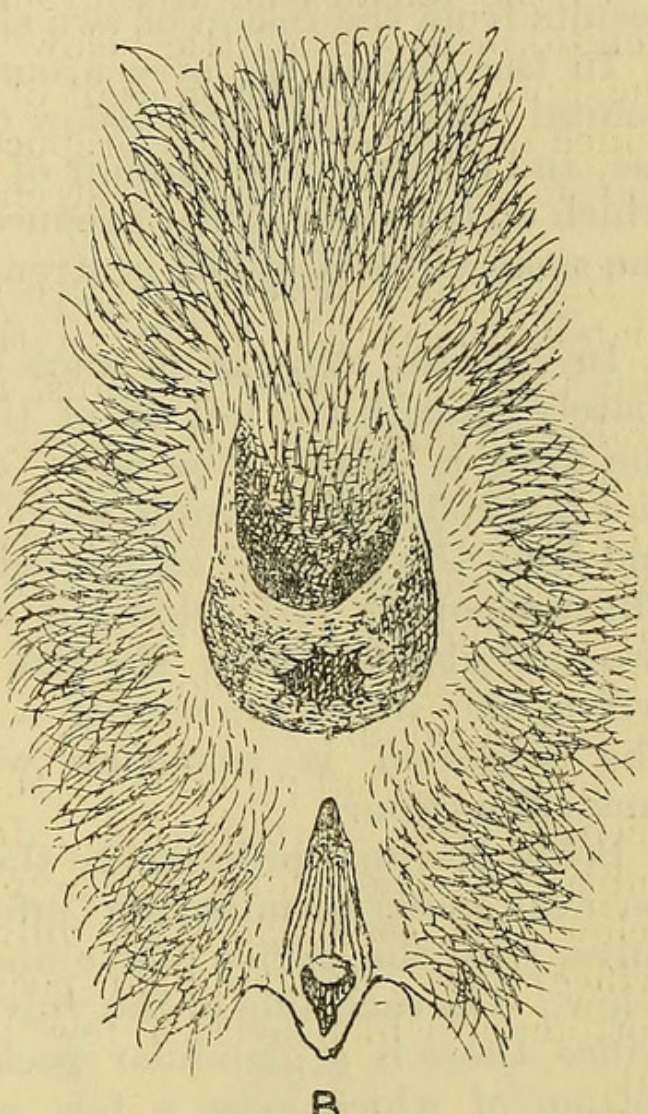

B

A. Rear end of Meles meles, male, showing the subcaudal and anal pouches distended nearly to the fullest extent.

B. The same of the female, but with the pouches rather less distended transversely.

Gairdner supplements this account as follows:- "Two scent glands were found discharging into the postcaurlal pocket. The secretion was brownish yellow and the hind parts were stained by the flow, and the stench so pervaded the beast that the cooliess were unable to eat it " $\uparrow$.

In the male of Meles the hairy scrotum is situated just below the rim of the circumanal sac, which, except in the midnle line, is covered with short hairs. The baculum has been figured and

* Journ. Asiatic Soc. Bengal, viii. pt. i. p. 408 (1839).

† Journ. Nat. Hist. Soc. Siam, i. no. 4, p. 253 (1915). From the passage quoted it appears that the secretion of the glands of Arctony $x$ is much stronger in smell than that of Meles. Meles has the habit, observable in Mongooses and Civets, with analogous glands, of rubbing the secretion on objects so that the scent is disseminated. 
described by Blumenbach * and Pohl $\uparrow$. It is about 4 inches long and slightly incrassate at the base, flattened and grooved beneath throughout its length and carinate above in its proximal half, then flattened and depressed, with a median dorsal groove up to the tip, which is straight or slightly upturned and expanded laterally into a roughened disc with semicircularly curved free margin. This apex is perfectly symmetrical, and an elongated slit perforating the bone behind the tip suggests that the latter results from the fusion of two short terminal processes.

In the female the area around the genitalia is smooth; the genital orifice is a little below the naked rim of the circumanal sac, and opens at the summit of an inferiorly expanding groove, which ends in an angular prepuce, forming a glandular space round the small clitoris, which is strengthened with a small bone,

In Taxidea there is no trace either of the deep pouch immediately beneath the tail or of the shallower depression in which the anus is sunk. The anus, on the contrary, is protuberant, and in profile view stands away from the base of the tail above and from the perineal region below like a hemispherical mound $\ddagger$. The anus opens just below the centre of this elevation, and the two anal glands, about the size of a hazel-nut, open within the orifice, the ducts traversing a definite papilla as in Mephitis. The secretion is colourless with a sweetish, not unpleasant musteline odour.

Below the anal prominence there is in the female a long naked perineal area, terminating inferiorly in a piriform prominent vulva, with the orifice above and a somewhat acuminate clitoris below. On each side of the vulva, a little below the level of the orifice, there is a glandular pocket about $6 \mathrm{~mm}$. deep, from the bottom of which arise a few setæ, each planted in a shallow pit.

Thus the anal and genital areas of the female Taxidea differ profoundly from those of Meles $\$$.

I have had no opportunity of examining a male Taxidea; but,

* Handbuch vergl. Anat. 1824, p. 476.

† Jena. Zeitschr. xlv. p. 385 (1909).

‡ Coues's statement (tom. cit. p. 267) that "the perinœal region shows, immediately beneath the root of the tail, a large transverse fissure leading into the peculiar subcaudal pouch of the Melince" is erroneous; and the error arose probably from the examination of dried skins, which were apparently all the material available for examination, judging from the bottom paragraph on p. 68 of the volume cited.

$\S$ It is possibie, however, that the difference in the size and situation of the genital orifice in the specimens examined may be more apparent than real. The examples of Meles were wild caught animals, one of which was known to have produced young before capture. The example of Taxidea, on the contrary, was received from New York as an adult specimen in 1910, and died, when an old animal, in Dec. 1918. Of her history previous to her arrival in London I know nothing, but she never bred nor was seen to pair with the maie after coming to the Gardens; and it may be that the small size and low position of the genital orifice and the consequent length of the perineal area are attributable to failure of copulation and parturition. 
according to Coues, there is a well-developed baculum. He describes it as " 4 inches long, clubbed at one end, compressed, and with a shallow sulcus in the continuity; the other end bent

Text-figure 22 .

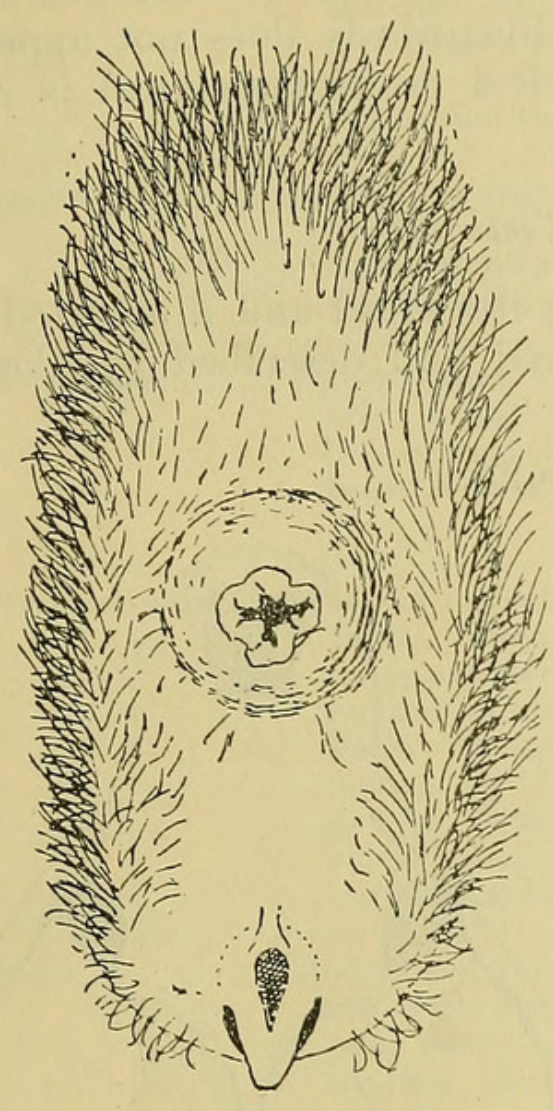

B

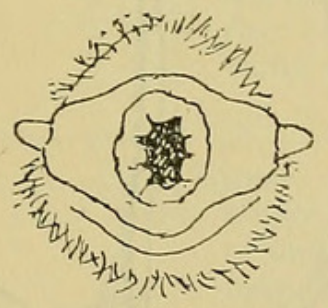

$\mathbf{F}$

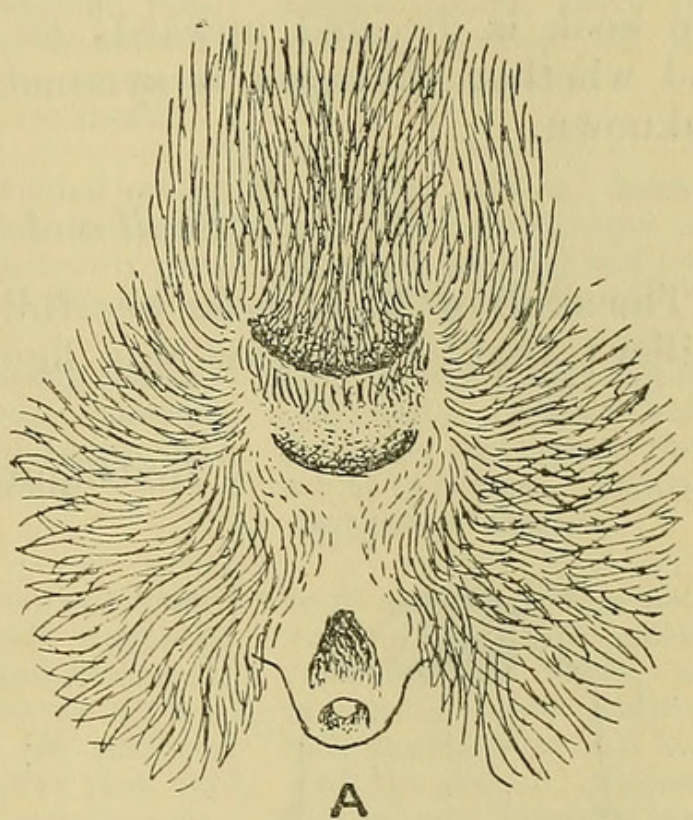

A

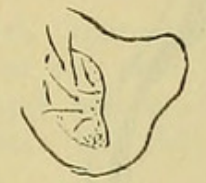

D

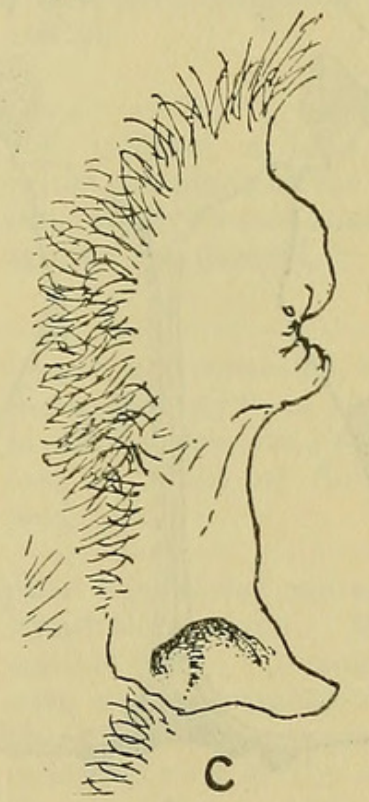

A. Rear end of Meles meles, female, with the subcaudal and anal sacs closed. $\times \frac{1}{2}$.

B. The same of Taxidea americana, female. $\times \frac{1}{2}$.

C. Lateral view of ano-genital area of Taxidea, female, showing the prominent anus and the clitoris with its lateral glandular pit partly opened. $\quad \times \frac{1}{2}$.

D. The lateral gland of the clitoris of the same, opened to show the setre at the bottom.

E. Clitoris of same, elevated to show the glandular pits closed.

F. Anus of same, spread open to show the papillæ of the anal glands. 
nearly at a right angle, abruptly and irregularly tlattened and grooved" (tom. cit. p. 269).

'This description is not very intelligible, and it is doubtful if the describer knew either the proximal from the distal extremity or the dorsal from the ventral surface; but $I$ infer that the bone is compressed, grooved throughout its extent below, thickened at the base and hooked at the apex, but whether the curvature of the hook is directed upwards or downwards does not appear; and whether the apex is symmetrical or asymmetrical is also unknown.

\section{Skull and T'eeth.}

The skull of Meles meles was fully ilescribed and illustrated by Miller; that of Taxidea was figured and described by Coues.

\section{Text-figure 23.}

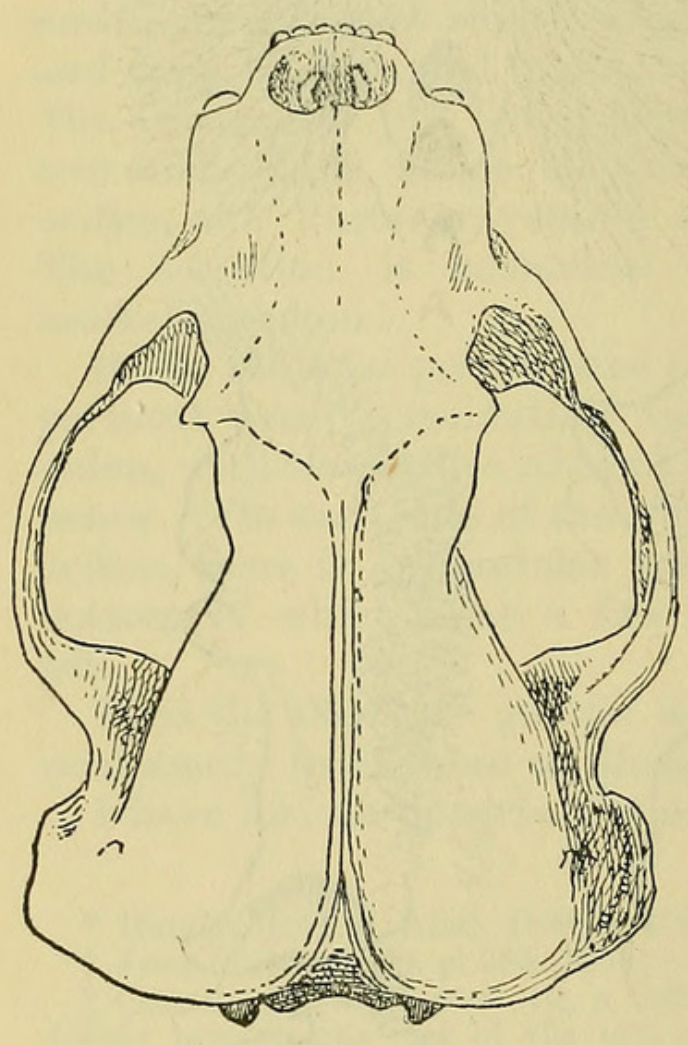

A

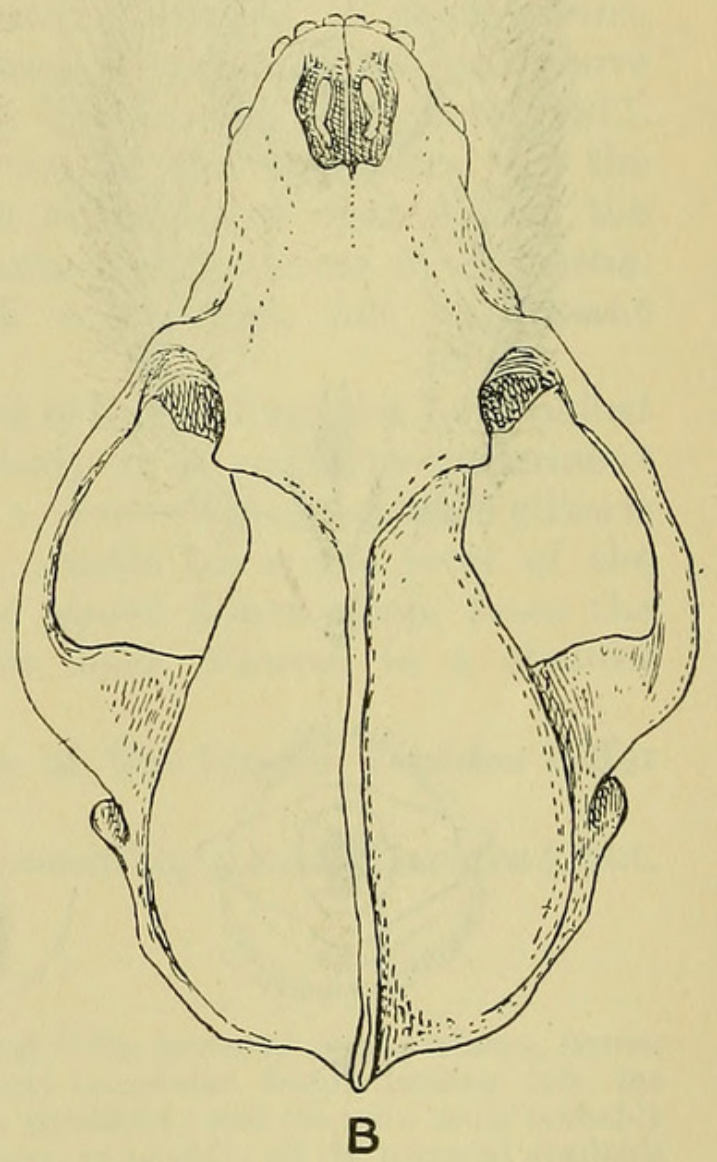

B

A. Upper view of the skull of Taxidea. $\times \frac{5}{8}$ approx.

B. The same of Meles.

Elliot also reprolucel photographs of it *, and Baird pointed out some of the differences between the two genera in the crania and teeth.

* Field Columb. Mus, ii. p. 320 (1901). 
In the following table the principal differences are placed side by side for comparison :-

\begin{tabular}{|c|c|c|}
\hline & Meles. & TAXIDEA. \\
\hline Muzzle & $\begin{array}{l}\text { Elongated, comparatively nar- } \\
\text { row, with prominent pre- } \\
\text { maxillæ. Infraorbital fora- } \\
\text { men large. above the anterior } \\
\text { portion of the upper molar } \\
\text { and behind the carnassial. }\end{array}$ & $\begin{array}{l}\text { Short and broad, with short } \\
\text { premaxillæ. Infraorbital } \\
\text { foramen small, abore the } \\
\text { anterior portion of the } \\
\text { upper carnassial. }\end{array}$ \\
\hline Zygomata & $\begin{array}{l}\text { Strongly saliant behind orbit } \\
\text { the posterior base expanded } \\
\text { laterally and posteriorly con- } \\
\text { siderably beyond glenoid. }\end{array}$ & $\begin{array}{l}\text { Moderately salient behind } \\
\text { orbit; its posterior base not } \\
\text { expanded laterally and pos- } \\
\text { teriorly beyond glenoid. }\end{array}$ \\
\hline Brain-case. & $\begin{array}{l}\text { Upper surface sloping posteri- } \\
\text { orly ; lateral walls rounded, } \\
\text { converging behind zygomata. } \\
\text { Sagittal crest high. }\end{array}$ & $\begin{array}{l}\text { Upper surface hardly sleping } \\
\text { posteriorly; lateral walls } \\
\text { gradually divergent firom } \\
\text { orbits to occiput. Sagittal } \\
\text { crest low or absent. }\end{array}$ \\
\hline Orcipital area & $\begin{array}{l}\text { Much na:rower than zygomatic } \\
\text { width. Mastoids compara- } \\
\text { tively narrow and elongated, } \\
\text { inclined downwards and for- } \\
\text { wards beneath the auditory } \\
\text { meatus and lower than the } \\
\text { glenoid. Basioceipito-sphe- } \\
\text { noilal plane inclined up- } \\
\text { wards from foramen. }\end{array}$ & $\begin{array}{l}\text { Almost as wide as zygomatic } \\
\text { width. Mastoids greatly } \\
\text { expanded but short, not } \\
\text { projecting below auditor! } \\
\text { meatus and about on a leve } \\
\text { with the glenoid. Basiocci- } \\
\text { pito-sphenoidal plane hor- } \\
\text { zontal. }\end{array}$ \\
\hline Bulla. & $\begin{array}{l}\text { Moderately inflated, scarcely } \\
\text { below the plane of the occ- } \\
\text { pital condyles and not ex- } \\
\text { tending forwards to the } \\
\text { glenoid. }\end{array}$ & $\begin{array}{l}\text { Much inflated, a long way } \\
\text { Lelow the plane of the occi. } \\
\text { pita! condyles and abutting } \\
\text { aginst the glenoid. }\end{array}$ \\
\hline Foramina & $\begin{array}{l}\text { For. rot. concealed and open- } \\
\text { ing a long vide for. lac. ant.; } \\
\text { for. ov. con-iderably in ad- } \\
\text { vance of for. lac. med. }\end{array}$ & $\begin{array}{l}\text { For. rot. not concealed, open- } \\
\text { ing separa' ely firom and be } \\
\text { neath fur. lac. ant.: for ov } \\
\text { just in front of for lac. } \\
\text { med. }\end{array}$ \\
\hline Teeth & 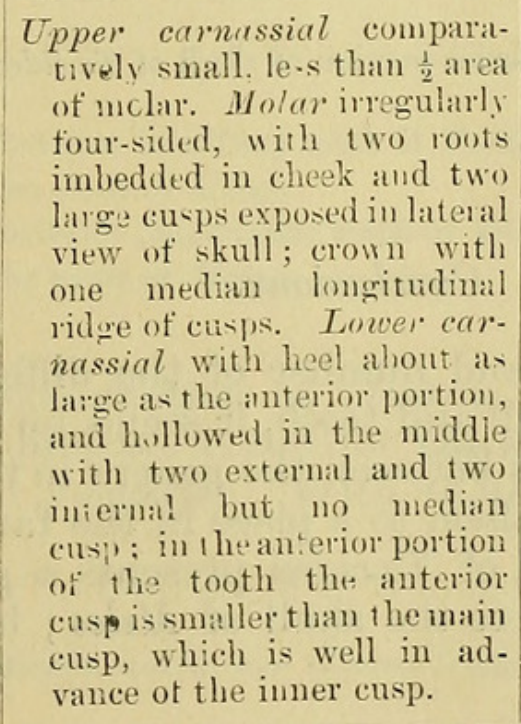 & 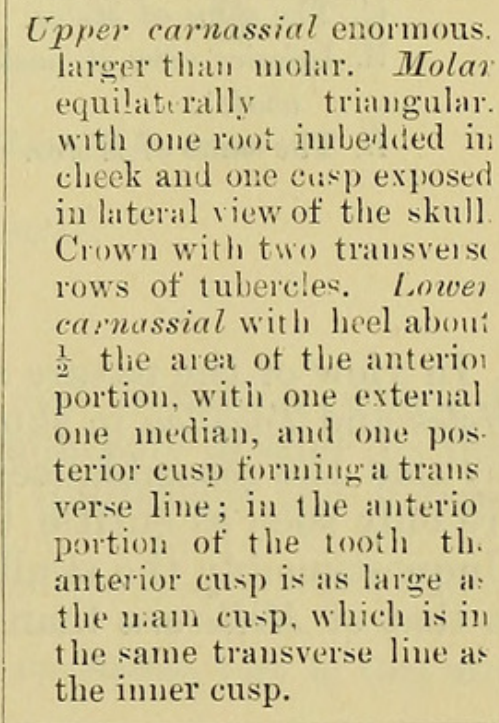 \\
\hline
\end{tabular}


Text-figure 24.
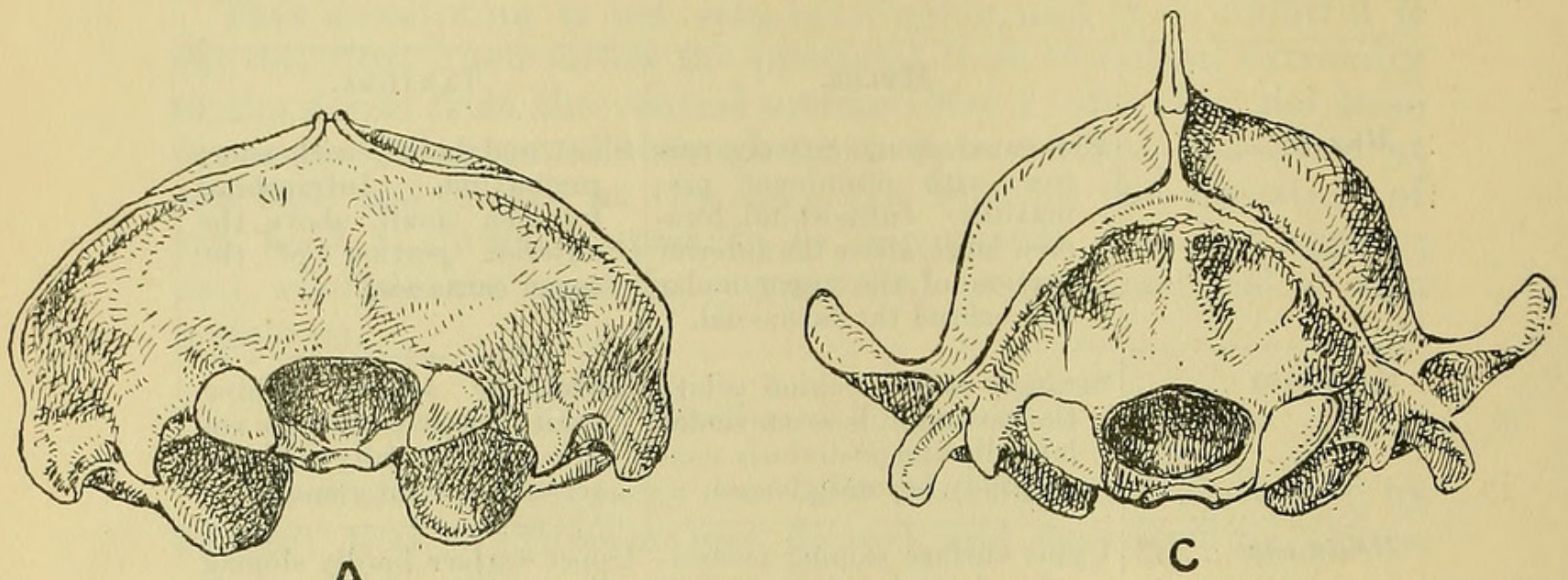

A

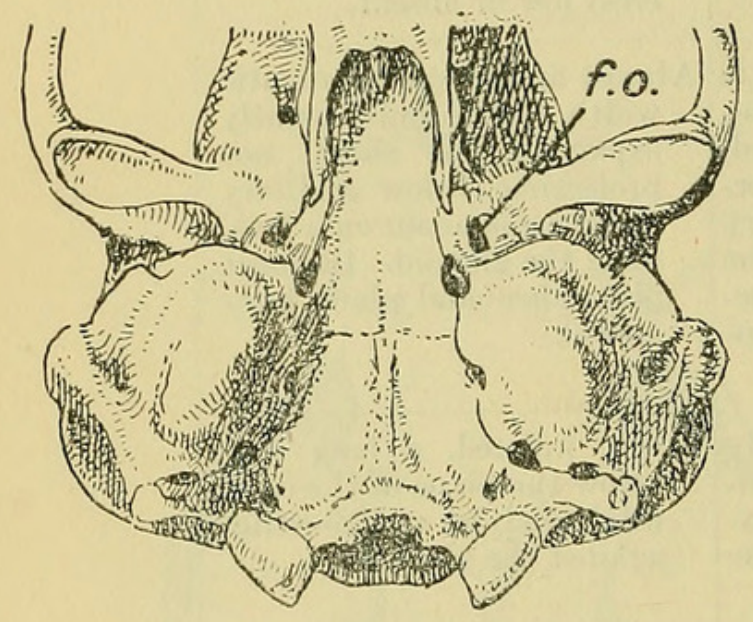

B

Taxides.

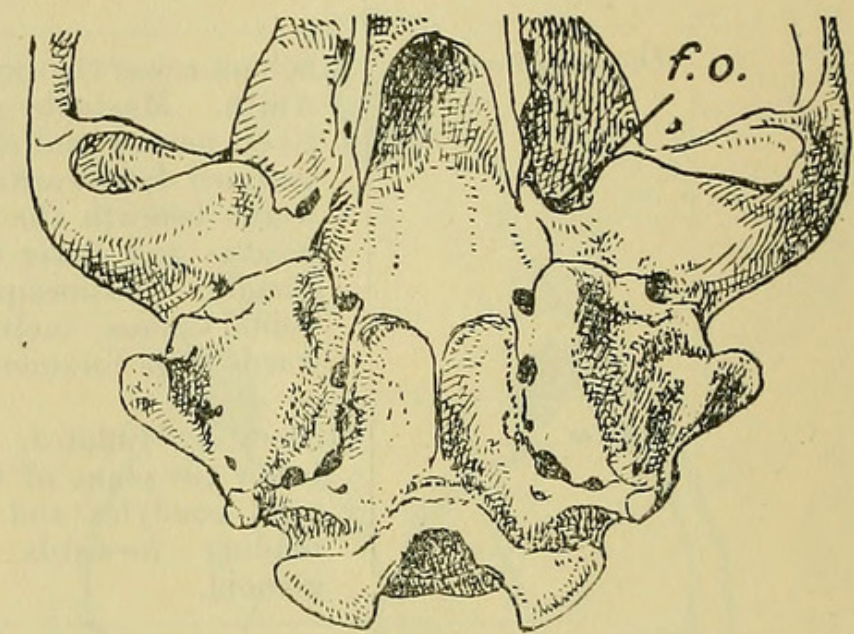

D

Meles.

A. Posterior view of the skull of Taxidea. $\times \frac{2}{3}$ approx.

C. The same of Meles.

B. Inferior riew of posterior portion of skull of Taxidea (f.o., foramen ovale).

D. The same of Meles.

\section{Conclusions.}

In view of the nature and number of the differences between Meles and Taxidea in skull and teeth, it seems no exaggeration to say that the resemblances between the genera in those particulars are only such as entitle them to a place in the family Mustelidæ. Unquestionably the skull of T'axidea presents a greater likeness to that of Mellivora than to the skull of Meles; but it is, in my 
opinion, by no means certain that this likeness involves close affinity, since the two genera differ considerably in the structure of the two posterior maxillary teeth and in the development of the pinna of the ear, of the pads on the feet, etc.

Text-figure 25 .

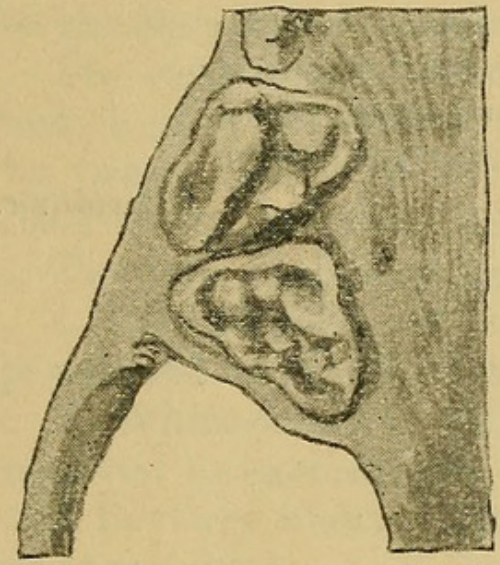

A

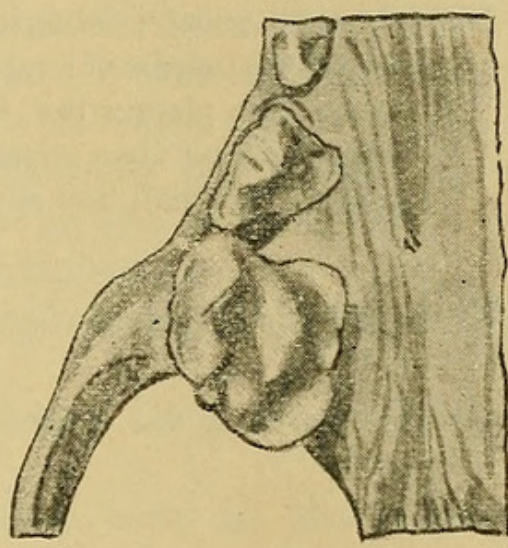

C

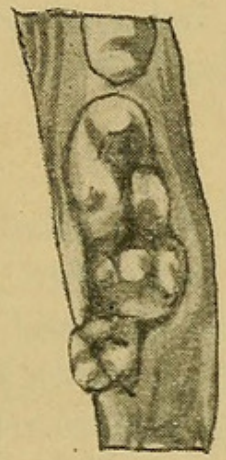

B

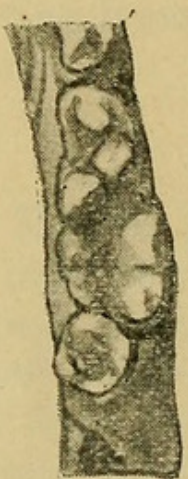

D

A. Posterior maxillary teeth of Taxidea. Nat. size.

C. The same of Meles.

B. Posterior mandibular teeth of Taxidea.

D. The same of Meles.

Pending an examination of Mydaus and Helictis:, which I have not seen, I propose to restrict the subfamily Melince to the genera Meles and Arctonyx. With these limitations the Melince Gill.

$$
\text { Proc. Zool. Soc. }-1920 \text {, No. XXIX. }
$$


may be briefly distinguished as follows from the Taxiidinæ, a new group which, for the present, contains Taxidea alone:-

a. A well-developed subcaudal pouch; rhinarium with very deep infranarial area ; plantar pads wide, carpal and metatarsal pads comparatively large, the latter on a naked area behind the plantar pad ; upper carnassial much smaller than quadrilateral molar; lower carnassial with enormous heel etc.

Melina.

$\boldsymbol{b}$. No subcaudal pouch; rhinarium with shallow infranarial area; plantar pads narrower; carpal pads much reduced, hind foot hairy down to plantar pad, metatarsal pads suppressed; upper carnassial larger than triangular molar; lower carnassial with comnaratively small heel etc.

Taxidiina. 


\section{$2 \mathrm{BHL}$ Biodiversity Heritage Library}

Pocook, R L. 1920. "25. On the External and Cranial Characters of the European Badger (Melei)and of the American Badger (Taxidea)*." Proceedings of the Zoological Society of London 1920, 423-436.

https://doi.org/10.1111/j.1469-7998.1920.tb07082.x.

View This Item Online: https://www.biodiversitylibrary.org/item/97660

DOI: https://doi.org/10.1111/j.1469-7998.1920.tb07082.x

Permalink: https://www.biodiversitylibrary.org/partpdf/72113

\section{Holding Institution}

Smithsonian Libraries

\section{Sponsored by}

Biodiversity Heritage Library

\section{Copyright \& Reuse}

Copyright Status: Public domain. The BHL considers that this work is no longer under copyright protection.

This document was created from content at the Biodiversity Heritage Library, the world's largest open access digital library for biodiversity literature and archives. Visit BHL at https://www.biodiversitylibrary.org. 